\title{
KINERJA GURU DIPENGARUHI OLEH KOMPETENSI GURU DAN KEPEMIMPINAN KEPALA SEKOLAH
}

\author{
Epa \\ STIE Cipasung, Tasikmalaya \\ epa.campus@gmail.com
}

\begin{abstract}
ABSTRAK
Penelitian ini mengkaji tentang optimalisasi kinerja guru dengan mengukur pengaruh kompetensi guru dan kepemimpinan kepala sekolah terhadap kinerja guru ekonomi. Metode yang digunakan adalah metode survei dan total sampling. Subjek penelitian terdiri dari 55 guru ekonomi di SMA di kota Tasikmalaya. Simpulan, kompetensi guru dan kepemimpianan Kepala Sekolah memiliki pengaruh positif terhadap kinerja guru dimana semakin tinggi kompetensi guru dan semakin efektif kepemimpinan Kepala Sekolah maka akan meningkatkan kualitas kinerja guru.
\end{abstract}

Kata Kunci: Kompetensi Guru, Kinerja Guru, Kepemimpinan Kepala Sekolah

\section{ABSTRACT}

This study examines the optimization of teacher performance by measuring the effect of teacher competence and principal leadership on economic teacher performance. The method used is survey method and total sampling. The research subjects consisted of 55 high school economics teachers in the city of Tasikmalaya. Conclusion, teacher competence and principal leadership have a positive influence on teacher performance where the higher the teacher competence and the more effective the principal's leadership, it will improve the quality of teacher performance.

Keywords: Teacher Competence, Teacher Performance, Principal Leadership

\section{PENDAHULUAN}

Pendidikan sebagai proses pembangunan sumber daya manusia di Indonesia masih belum sesuai dengan harapan, hal tersebut disebabkan tiga hal, pertama fungsi pendidikan sebagai proses transformasi budaya yang berarti proses pewarisan budaya bangsa dari generasi ke generasi yang selanjutnya malah disorientasi dengan nilai-nilai budaya yang seharusnya diwariskan; kedua yaitu fungsi pendidikan sebagai proses pembentukan pribadi masih terbatas pada aspek kognitif, padahal aspek afektif dan aspek psikomotor juga mempunyai peranan penting.

Mengingat kembali fenomena lainnya, kontroversi ujian nasional (UN) sebagai satu-satunya penentu kelulusan siswa. Keberadaan UN penting tetapi 
dalam fungsi pendidikan sebagai pengembangan pribadi siswa, keberhasilannya bukan hanya diukur dari keberhasilan menjawab soalnya, tetapi juga perubahan sikap dan perilakunya; dan ketiga fungsi pendidikan sebagai penyiapan tenaga kerja yang berarti bahwa pendidikan harus mampu membimbing dan membekali siswanya agar mempunyai bekal dalam bekerja, faktanya masih banyak lulusan yang belum siap kerja.

Guru sebagai salah satu praktisi pendidikan menjadi kunci keberhasilan pendidikan itu sendiri. Bagaimana tidak, guru adalah orang yang langsung terlibat dalam proses pendidikan yaitu proses pembelajaran. Menurut Tirtarahardja \& La Sulo (2005) guru sebagai pendidik ialah orang yang bertanggung jawab terhadap pelaksanaan pendidikan dengan sasaran peserta didik. Lebih praktis, Sukmadinata (2010) menjelaskan guru memegang peranan yang cukup penting baik dalam perencanaan maupun pelaksanaan kurikulum. Dia adalah perencana, pelaksana, dan pengembang kurikulum bagi kelasnya.

Menurut Undang-undang No.14 Tahun 2005 pasal 10 ayat 1, kompetensi yang harus dimiliki oleh guru meliputi kompetensi pedagogik, kompetensi kepribadian, kompetensi sosial, dan kompetensi profesional yang diperoleh melalui pendidikan profesi. Variabel kompetensi guru dalam penelitian ini yaitu mencakup pedagogical content knowledge (PCK). Peran guru dalam pendidikan adalah sebagai pemelihara (conservator), pengembang (innovator), penerus (transmitter), penerjemah (translator) serta penyelenggara (organizer) (Kirom, 2017). Menyadari peran dan tugas yang diemban guru, persoalan pendidikan pada level mikro yang menarik untuk dikaji pada penelitian ini adalah tentang kinerja guru.

Kinerja guru pada dasarnya adalah hasil kerja yang tunjukkan oleh guru dalam melaksanakan kewajibannya. Kinerja guru akan sangat menentukan kualitas hasil proses pendidikan. Dalam hal ini, salah satu indikator kinerja guru sebagai suatu output dapat kita cermati dari hasil belajar peserta didik. Sementara keberhasilan guru di sekolah tidak terlepas dari peran kepemimpinan yang dimiliki oleh seorang Kepala Sekolah tersebut. Kepala Sekolah merupakan orang yang bertanggung jawab terhadap pekerjaan guru dan staff sekolah serta melakukan pembinaan terhadap guru untuk meningkatkan kemampuan dalam melaksanakan tugasnya (Mantja, 2005). Selain itu, Kepala Sekolah juga melakukan pengawasan dan pengendalian terhadap kinerja guru. Suhartiningsih (2010) mengatakan bahwa Kepala Sekolah dapat melakukan pengawasan dan pengendalian terhadap kinerja guru melalui diskusi kelompok, kunjungan kelas, serta mengikutsertakan guru dalam kegiatan seminar, lokakarya, dan lain-lain, serta membimbing guru dalam melaksanakan remedial teaching (perbaikan pengajaran). 
Studi di Kota Tasikmalaya, berdasarkan hasil survey data diperoleh bahwa nilai rata-rata terendah UN pada tahun pelajaran 2010-2011 SMA sebesar 6.40, dimana melihat nilai angka perolehan tersebut mengakibatkan lulusan kurang mampu bersaing dalam menghadapi tuntutan jaman, dimana nilai tinggi masih menjadi salah satu indikator pengguna lulusan sebuah sekolah.

Berkaitan dengan masalah kurang optimalnya kinerja guru, kinerja guru dalam pembelajaran menjadi bagian terpenting dalam mendukung terciptanya proses pendidikan secara efektif terutama dalam membangun sikap disiplin dan mutu hasil belajar (Husdarta, 2007). Kinerja guru dalam penelitian ini dipengaruhi oleh beberapa faktor, yaitu variabel individu, variabel organisasi dan variabel psikologis (Gibson, 1992). Pertama, faktor individual yaitu kemampuan dan keterampilan, latar belakang (keluarga, tingkat sosial, pengalaman), demografis (umur, etnis, jenis kelamin); kedua, faktor psikologis yaitu (motivasi, sikap, kepribadian, belajar, persepsi); dan ketiga, faktor organisasi kaitannya dengan iklim, kepemimpinan, sumber daya, imbalan, struktur, dan desain pekerjaan.

Optimalisasi kinerja guru melalui peningkatan pemahaman disiplin kerja dan motivasi guru menyatakan bahwa motivasi memiliki pengaruh yang signifikan terhadap kinerja guru namun disiplin kerja tidak memiliki pengaruh yang signifikan terhadap kinerja guru (Sulistyaningsih, 2016). Kesuksesan optimalisasi kinerja guru juga dipengaruhi oleh upaya kepala sekolah seperti pembinaan, suprvisi dan menciptakan iklim sekolah yang kondusif (Suhartiningsih, 2010). Hardianto (2018) kinerja guru dapat ditingkatkan melalui dua cara yaitu memberi penghargaan dan meningkatkan motivasi guru. Hardianto juga berharap kepala sekolah dapat berperan dalam meningkatkan kinerja guru.

Berdasarkan beberapa penelitian sebelumnya, maka penelitian ini peneliti ingin mengukur pengaruh tingkat kompetensi guru dan efektifitas kepemimpinan Kepala Sekolah secara bersama-sama terhadap optimalisasi kualitas kinerja guru ekonomi SMA di kota Tasikmalaya.

\section{METODE PENELITIAN}

Penelitian ini pada dasarnya memiliki tujuan untuk memecahkan masalah. Adapun penyelesaian masalah penelitian ini menggunakan pendekatan kuantitatif, yakni yang mementingkan adanya variabel-variabel sebagai objek penelitian dan variabel-variabel tersebut harus didefinisikan dalam bentuk operasional variabel masing-masing. Selanjutnya metode yang akan digunakan dalam penelitian ini adalah survei. Survey adalah prosedur dalam penelitian kuantitatif untuk mengidentifikasi sikap, pendapat, karakterisitik dan lain-lain dalam suatu populasi. Metode survei karena data yang akan digunakan merupakan data kuantitatif, teknik pengumpulan data yang akan digunakan adalah kuesioner dan penelitian ini menggunakan sampel penelitian sebanyak 55 responden (guru 
ekonomi). Penelitian ini bertujuan untuk menganalisa kompetensi guru, kepemimpinan Kepala Sekolah dan kinerja guru ekonomi di SMA Tasikmalaya.

Adapun teknik analisis data yang digunakan dalam penelitian ini, yaitu tahap deskripsi data, tahap uji persyaratan analisis, dan tahap pengujian hipotesis. Selanjutnya uji analisis data dilakukan melalui uji regresi linear, uji korelasi, dan uji determinasi.

\section{HASIL PENELITIAN}

Untuk mengetahui besarnya pengaruh tingkat kompetensi guru dan efektifitas kepemimpinan Kepala Sekolah secara bersama-sama terhadap kualitas kinerja guru ekonomi SMA di kota Tasikmalaya, dapat dilakukan dengan menggunakan analisis regresi linier berganda.

\section{Regresi Linier Berganda}

Hasil perhitungan diperoleh bahwa persamaan regresi berganda $\mathrm{Y}=\mathrm{a}+\mathrm{b} 1 \mathrm{X} 1+\mathrm{b} 2 \mathrm{X} 2$. Maka diperoleh persamaan regresi sebagai berikut :

$\mathrm{Y}=17.863+0.418 \mathrm{X} 1+0.526 \mathrm{X} 2$

Berdasarkan persamaan tersebut dapat diinterprestasikan bahwa nilai konstanta $\mathrm{a}=17.863$ dan koefisien $\mathrm{b} 1=0.418$ dan $\mathrm{b} 2=0.526$. Hal ini berarti jika dihitung dengan satuan angka maka kompetensi guru dan kepemimpinan Kepala Sekolah ditingkatkan sebanyak satu kali, sehingga kinerja guru ekonomi meningkat sebesar 18.807. Apabila tidak melakukan kompetensi guru dan kepemimpinan Kepala Sekolah atau (X1, X2 =0) maka kinerja guru ekonomi hanya sebesar 17.863 hal ini ditimbulkan dari variabel lain yang tidak penulis teliti.

\section{Uji Determinasi}

Agar dapat mengetahui Pengaruh tingkat kompetensi guru dan efektifitas kepemimpinan Kepala Sekolah secara bersama-sama terhadap tingkat kualitas kinerja guru ekonomi SMA di Kota Tasikmalaya dapat diukur dengan koefisien determinasi. Berdasarkan tabel di atas diperoleh nilai $r^{2}=0,533$, yang artinya bahwa pengaruh tingkat kompetensi guru dan efektifitas kepemimpinan Kepala Sekolah secara bersama-sama terhadap tingkat kualitas kinerja guru ekonomi SMA di Kota Tasikmalaya sebesar 0,533 atau sebesar 53.3\% sisanya dipengaruhi oleh faktor lain yaitu sebesar $46.7 \%$.

Untuk melihat pengaruh tingkat kompetensi guru terhadap tingkat kualitas kerja guru ekonomi SMA di Kota Tasikmalaya dapat dilihat dari indikatorindikator yang mempengaruhinya. Pengaruh tersebut dapat dilihat dari gambar dibawah ini: 


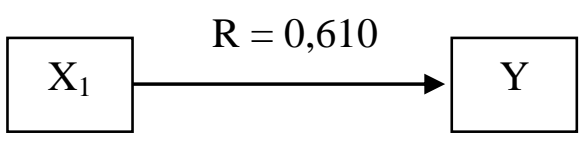

Gambar 1. Nilai Koefisien Jalur Antara Variabel $\mathrm{X}_{1}$ dan Variabel Y

Berdasarkan pengolahan data dengan menggunakan SPSS, besar pengaruh kompetensi guru $\left(\mathrm{X}_{1}\right)$ terhadap kinerja guru ekonomi $(\mathrm{Y})$ sebesar 0,610 hal ini berarti hubungan antara kompetensi guru dengan kinerja guru memiliki hubungan kuat. Selanjutnya untuk koefisien determinasi sebesar 0,372 atau sebesar 37.2\%. hal ini berarti bahwa pengaruh kompetensi guru sebesar $37.2 \%$ mempengaruhi terhadap kinerja kerja guru ekonomi SMA di Kota Tasikmalaya.

Untuk pengujian hipotesis antara kompetensi guru $\left(\mathrm{X}_{1}\right)$ terhadap kinerja guru (Y). Dengan kriteria penolakan Ho, jika $t_{\text {hitung }}>t_{\text {tabel }}$, maka nilai $\mathrm{R}$ sebesar 0.610, diperoleh $t_{\text {hitung }}$ sebesar 5.598 dengan mengambil taraf signifikansi sebesar $5 \%$ maka nilai $t_{\text {tabel }} 2.005$. Sehingga $t_{\text {hitung }}>t_{\text {tabel }}$, maka tolak Ho atau dengan kata lain kompetensi guru berpengaruh signifikan terhadap kinerja guru ekonomi se Kota Tasikmalaya. Selanjutnya untuk melihat pengaruh tingkat kepemimpinan Kepala Sekolah terhadap kualitas kerja guru ekonomi SMA di Kota Tasikmalaya dapat dilihat dari indikator-indikator yang mempengaruhinya. Dimana pengaruh tersebut dapat dilihat dari gambar dibawah ini :

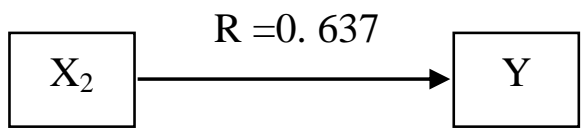

Gambar 2. Nilai Koefisien Jalur Antara Variabel $\mathrm{X}_{2}$ dan Variabel Y

Berdasarkan pengolahan data dengan menggunakan SPSS, besar pengaruh kepemimpinan Kepala Sekolah $\left(\mathrm{X}_{2}\right)$ terhadap kinerja guru ekonomi (Y) sebesar 0,637 hal ini berarti hubungan antara kepemimpinan Kepala Sekolah dengan kinerja guru memiliki hubungan kuat. Selanjutnya untuk koefisien determinasi sebesar 0,406 atau sebesar 40.6\%. hal ini berarti bahwa pengaruh kepemimpinan kepala skeolah sebesar $40.6 \%$ mempengaruhi terhadap kinerja kerja guru ekonomi SMA di Kota Tasikmalaya.

Untuk pengujian hipotesis antara kepemimpinan Kepala Sekolah $\left(\mathrm{X}_{2}\right)$ terhadap kinerja guru (Y). Dengan kriteria penolakan Ho, jika $t_{\text {hitung }}>t_{\text {tabel }}$, maka nilai $\mathrm{R}$ sebesar 0.610 , diperoleh $\mathrm{t}_{\text {hitung }}$ sebesar 0.016 dengan mengambil taraf signifikansi sebesar $5 \%$ maka nilai $t_{\text {tabel }} 2.005$. Sehingga $t_{\text {hitung }}>t_{\text {tabel }}$, maka tolak Ho atau dengan kata lain kompetensi guru berpengaruh signifikan terhadap kinerja guru ekonomi se Kota Tasikmalaya. 
Besarnya pengaruh kompetensi guru $\left(\mathrm{X}_{1}\right)$, kepemimpinan Kepala Sekolah $\left(\mathrm{X}_{2}\right)$ terhadap kinerja guru $(\mathrm{Y})$, dapat dilihat dari indikator yang digunakan masing-masing variabel, dengan menggunakan regresi linear berganda. Setelah melakukan penelitian dan memperoleh data-data yang diperlukan maka dilakukan pengujian hipotesis yang diajukan. Pengujian hipotesis secara bersama-sama tersebut menggunakan uji $\mathrm{F}$ yaitu untuk menguji apakah terdapat pengaruh secara signifikan antara desain produk dan ragam produk terhadap keputusan penggunaan layanan, dimana hasil dan pengolahan data melalui SPSS. Pengaruh secara simultan dapat dilihat pada lampiran SPSS, dimana $\mathrm{P}^{2} \mathrm{yx}_{1} \mathrm{x}_{2}$ ) yaitu sebesar 0.533 artinya jika kompetensi guru dan kepemimpinan Kepala Sekolah bersama-sama dapat meningkat atau memberikan dampak positif terhadap kinerja guru.

Untuk pengujian hipotesis secara simultan dengan perumusan hipotesis sebagai berikut :

$$
\begin{array}{ll}
\mathrm{H}_{\mathrm{o}}: \rho \mathrm{YX}_{1} & =\rho \mathrm{YX}_{2}<0 \\
\mathrm{Ha}: \rho \mathrm{YX}_{1} & =\rho \mathrm{YX}_{2} \geq 0
\end{array}
$$

Dengan menggunakan rumus:

$$
F=\frac{(n-k-1) R^{2} Y X_{1} X_{2} \ldots \ldots \ldots . . . X k}{K\left(1-R^{2} Y X_{1} X_{2} \ldots \ldots \ldots . . . X k\right.}
$$

Dari hasil perhitungan SPSS, diperoleh nilai $F_{\text {hitung }}$ sebesar 29.681 dengan kriteria penolakan $\mathrm{H}_{\mathrm{o}}$, jika $\mathrm{F}_{\text {hitung }}>\mathrm{F}_{\text {tabel}}$, dengan mengambil taraf signifikan $\alpha$ sebesar $5 \%$, maka diperoleh $\mathrm{F} \alpha ; \mathrm{k} ;(\mathrm{n}-\mathrm{k}-1)=2-52-1$ adalah sebesar 3.618 atau cukup melihat sig F yaitu 0,000 yang artinya dengan $\alpha$ lebih kecil dari $5 \%$ masih menunjukkan signifikan. Dikarenakan 29.681 lebih besar dari 3.618 dengan sig F sebesar 0,000, maka Ho ditolak atau Ha diterima dengan kata lain kompetensi guru $\left(\mathrm{X}_{1}\right)$ dan kepemimpinan Kepala Sekolah $\left(\mathrm{X}_{2}\right)$ secara simultan berpengaruh signifikan terhadap kinerja guru ekonomi SMA di Kota Tasikmalaya (Y) sebesar koefisien determinasi 0,533 atau $53.3 \%$.

\section{PEMBAHASAN}

Berdasarkan hasil penelitian menunjukan kompetensi guru termasuk dalam kategori tinggi. Kompetensi guru yang paling tinggi yaitu tentang kemampuan guru ekonomi memacu peserta didik untuk berfikir kreatif dan skor terkecil tentang penggunaan LKS yang dibeli sekolah dari percetakan. Tingkat kompetensi guru ekonomi SMA di Tasikmalaya sudah memenuhi tingkat kompetensi yang distandarkan, juga implikasinya dapat dirasakan oleh peserta didik dengan kondisi bahan ajar yang diprediksi seadanya karena penggunaan LKS yang skornya sedang. 
Penelitian ini juga menunjukan bahwa kepemimpinan Kepala Sekolah menunjukan kategori sangat efektif. Hasil penelitian menunjukkan bahwa kepemimpinan Kepala Sekolah di SMA di Tasikmalaya sangat efektif. Kepala Sekolah bertanggung jawab terhadap kemajuan prestasi sekolah, guru, dan peserta didiknya. Kepemimpinan yang efektif dan positif inilah yang dapat mendukung serta mewujudkan lingkungan sekolah yang kondusif. Seperti pendapat Chen, et.al (2016) bahwa kepemimpinan positif memiliki hubungan yang signifikan dengan efektifitas sekolah melalui budaya organisasi di sekolah. Kepemimpinan kepala sekolah sangat menentukan pengembangan serta peningkatan sekolah untuk kedepannya, kepala sekolah harus memiliki gaya kepemimpinan seperti, manajerial, transformasional, transaksional, pengajaran serta pikiran positif (Gaol, 2017). Sehingga dengan adanya kepemimpinan Kepala Sekolah yang efektif ini, sekolah telah merasakan kerja keras Kepala Sekolah serta mempengaruhi kinerja guru menjadi semakin meningkat.

Sementara kinerja guru ekonomi menunjukan dalam kategori tinggi. Kinerja guru merupakan hasil kerja guru yang selama melakukan kegiatan belajar mengajar serta pembuatan administrasi sesuai dengan petunjuk. Hasil deskripsi data terhadap kinerja guru diperoleh bahwa skor tertinggi dari kinerja guru ekonomi ini adalah tentang menentukan tujuan pembelajaran, memperhatikan kejelasan kriteria pencapaian tujuan dan skor terkecil mengenai pelaksanaan remidial teaching sebelum remidial test.

Kinerja manusia dipengaruhi oleh kondisi lingkungan internal dan eksternal, termasuk budaya organisasi. Sehingga, dengan adanya kepemimpinan yang baik maka guru akan meningkatkan komitmen serta loyalitas mereka dalam mengerjakan tugas-tugas yang diberikan (Hasan, 2017). Kepala sekolah juga dapat memberikan upaya seperti, (a) memaksimalkan peningkatan kompetensi guru, (2) mengalokasikan anggaran untuk peningkatan profesionalisme guru, (3) memberi saran serta bimbingan secara langsung pada guru, (4) menciptakan budaya organisasi sekolah yang kondusif, (5) menciptakan pembaruan, serta (6) memberi penghargaan kepada guru yang kinerjanya baik (Gaol \& Siburian, 2018). Guru yang memperoleh penghargaan atas kerja kerasnya dapat memperoleh kepuasan dalam bekerja. Sehingga guru bisa lebih termotivasi lagi dalam melaksanakan tugasnya dan kinerjanya bisa meningkat.

\section{SIMPULAN}

Berdasarkan hasil penelitian disimpulkan bahwa kompetensi guru berpengaruh positif terhadap kinerja guru ekonomi. Artinya, semakin tinggi tingkat kompetensi guru, maka kualitas kinerja guru akan meningkat. Sementara kepemimpinan Kepala Sekolah juga berpengaruh positif terhadap kinerja guru, artinya semakin efektif kepemimpinan Kepala Sekolah maka kualitas kinerja guru 
semakin meningkat. Kompetensi guru dan kepemimpianan Kepala Sekolah memiliki pengaruh positif terhadap kinerja guru dimana semakin tinggi kompetensi guru dan semakin efektif kepemimpinan Kepala Sekolah maka akan meningkatkan kualitas kinerja guru.

\section{DAFTAR PUSTAKA}

Chen, C., Tsai, S., Chen, H., \& Wu, H. (2016). The Relationship between the Principal's Positive Leadership and School Effectiveness-Take School Organizational Culture as The Mediator. European Journal of Psychological Research, 3(2), 12-23.

Gaol, N. T. L. (2017). Teori dan Implementasi Gaya Kepemimpinan Kepala Sekolah. Kelola: Jurnal Manajemen Pendidikan, 4(2), 213-219. https://doi.org/https://doi.org/10.24246/j.jk.2017.v4.i2.p213-219

Gaol, N. T. L., \& Siburian, P. (2018). Peran Kepala Sekolah dalam Meningkatkan Kinerja Guru. Kelola: Jurnal Manajemen Pendidikan, 5(1), 66-73.

Gibson. (1992). Organisasi: Perilaku, Struktur, dan Proses. Jakarta: Erlangga.

Hardianto, H. (2018). Optimalisasi Kepuasan Kerja Guru. Kelola: Jurnal Manajemen Pendidikan, 5(2), 190-195. https://doi.org/10.24246/j.jk.2018.v5.i2.p190-195

Hasan, M. N. (2017). Influence of Work Motivation, Leadership and Organizational Culture Principal of the Teacher Performance in Vocational School (SMK) Muhammadiyah, Rembang City, Central Java Province, Indonesia. European Journal of Business and Management, 9(2), 36-44.

Husdarta. (2007). Manajemen Pendidikan Jasmani. Bandung: Alpabeta.

Kirom, A. (2017). Peran Guru dan Peserta Didik dalam Proses Pembelajaran Berbasis Multikultural. Al-Murabbi: Jurnal Pendidikan Agama Islam, 3(1). Retrieved from http://jurnal.yudharta.ac.id/v2/index.php/pai

Mantja, W. (2005). Manajemen Pendidikan dan Supervisi Pengajaran. In Kumpulan Karya Tulis Terpublikasi. Malang: Penerbit Wineka Media.

Suhartiningsih. (2010). Optimalisasi Kinerja Guru dalam Proses Pembelajaran di Sekolah Dasar. Paedagogia: Jurnal Penelitian Pendidikan, 13(2), 103-114.

Sukmadinata, N. S. (2010). Landasaran Psikologi Proses Pendidikan. Bandung: PT. Rosdakarya.

Sulistyaningsih, S. (2016). Optimalisasi Kinerja Guru melalui Peningkatan Pemahaman Disiplin Kerja dan Motivasi Guru dalam Kegiatan Belajar Mengajar pada SLB-CG YPPCG Bina Sejahtera Surakarta. Jurnal Rehabilitasi Dan Remediasi, 25(1), 35-44.

Tirtarahardja, U., \& La Sulo, L. S. (2005). Pengantar Pendidikan. Jakarta: Rineka Cipta. 